(1) norden

\title{
LIGESTILLINGSVURDERING I STATSLIGE MYNDIGHEDERS ARBEJDE
}

- Resultater og anbefalinger fra en tværnordisk kortlægning

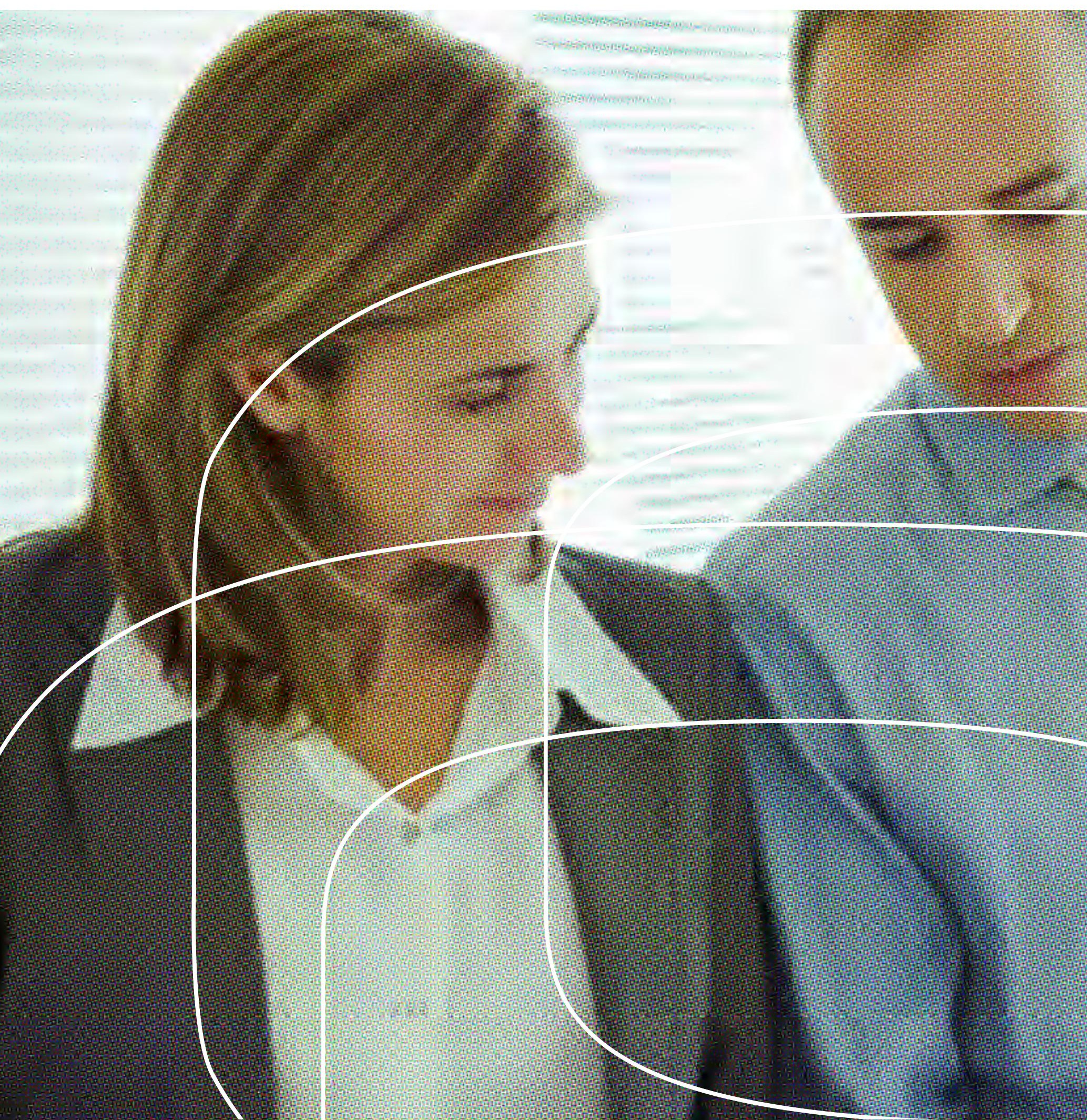


Ligestillingsvurdering i statslige myndigheders arbejde

- Resultater og anbefalinger fra en tværnordisk kortlægning

ISBN 978-92-893-4093-9 (PRINT)

ISBN 978-92-893-4094-6 (PDF)

http://dx.doi.org/10.6027/ANP2015-746

ANP 2015:746

(c) Nordisk Ministerråd 2015

Layout: Gitte Wejnold

Omslagsfoto: SignElements.com

Foto: SignElements.com

Skrift: Meta LF

www.norden.org/da/publikationer

\section{Det nordiske samarbejde}

Det nordiske samarbejde er en af verdens mest omfattende regionale samarbejdsformer. Samarbejdet omfatter Danmark, Finland, Island, Norge og Sverige samt Færøerne, Grønland og Åland.

Det nordiske samarbejde er både politisk, økonomisk og kulturelt forankret, og er en vigtig medspiller i det europæiske og internationale samarbejde. Det nordiske fællesskab arbejder for et stærkt Norden i et stærkt Europa.

Det nordiske samarbejde ønsker at styrke nordiske og regionale interesser og værdier i en global omverden. Fælles værdier landene imellem er med til at styrke Nordens position som en af verdens mest innovative og konkurrencedygtige regioner.

\section{Nordisk Ministerråd}

Ved Stranden 18

DK-1061 Copenhagen K

Telefon (+45) 33960200 


\section{LIGESTILLINGSVURDERING I STATSLIGE MYNDIGHEDERS ARBEJDE}

- Resultater og anbefalinger fra en tværnordisk kortlægning 


\section{INDHOLD}

Ligestilling i en tværnordisk kontekst 6

Udbytte af at foretage ligestillingsvurderinger $\quad 8$

$\begin{array}{ll}\text { Model for arbejdet med ligestillingsvurdering } & 10\end{array}$

Anbefalinger til arbejdet med ligestillingsvurdering 13

1.1.1 Politik og målsætninger for ligestillingsvurdering af kerneydelser 14

1.1.2 Målsætninger for ligestillingsvurdering af kerneydelser 16

1.1.3 Redskaber til arbejdet med ligestillingsvurderinger 18

1.1.4 Resultater og effekter - og dokumentation heraf 20

$\begin{array}{ll}\text { Yderligere viden } & 22\end{array}$ 


\section{LIGESTILLING I EN TVAERNORDISK KONTEKST}

\section{HVAD ER LIGESTILLINGSVURDERING?}

Begrebet ligestillingsvurdering dækker over en metode, som handler om at indarbejde et køns- og ligestillingsperspektiv i offentlig forvaltning og planlægning, hvor køn kan have en betydning. Det handler om, at politiske beslutninger og kerneydelser udarbejdes på baggrund af et oplyst grundlag og på baggrund af en bevidsthed om, at køn er en faktor, der har betydning for alle politikområder.

Når ligestilling indarbejdes i lovgivning og aktiviteter, fokuseres der på, hvorvidt de forskelle, der kan være mellem køn på et givent fagområde, giver anledning til særlige indsatser eller til, at indsatser skal udformes anderledes for at nå den relevante målgruppe. Det vil ofte være nødvendigt at koble køn med andre parametre fx uddannelse, civilstand, etnicitet, alder mv. for at få et tilstrækkeligt præcist billede af målgruppen og dermed grundlag for at målrette indsatsen mv.

Begrebet ligestillingsvurdering bruges i Danmark. I de andre nordiske lande benyttes begreberne "Integrering av könsperspektiv/Jämstallhetsintegrering" (FI), "Kynjasampætting/kønsintegrering" (IS), "Sektoransvar for integrering av kjønnslikestilling "(NO) og "Jämstallhetsintegrering" (SE).

De nordiske lande er generelt karakteriseret ved et omfattende fokus på kønsligestilling og har historisk haft en høj grad af ligestilling mellem kvinder og mænd og piger og drenge sammenlignet med andre lande. Dette gør sig gældende i uddannelsessystemet, på arbejdsmarkedet, $\mathrm{i}$ det politiske system og i samfundet generelt. Dette afspejles ligeledes ved, at de nordiske lande ligger $h ø j t$ på the 'Global Gender Gap Index', hvor Island bl.a. har ligget nummer ét fem år i træk ${ }^{1}$. Til trods for de nordiske landes $h ø j e$ rangeringer i internationale sammenligninger vedrørende ligestilling mellem $\mathrm{k} ø n$ nene, er det forsat vigtigt at have fokus på at styrke arbejdet med ligestilling/ligestillingsvurdering, da kvinder og mænd har forskellige behov og adfærd, som kan påvirke deres muligheder for at udnytte deres ressourcer fuldt ud i samfundet og deres hverdag.

\section{Denne pjece sætter fokus på} resultaterne af en kortlægning af arbejdet med ligestillingsvurderinger af kerneydelser på statsligt niveau på tværs af de nordiske lande. Kortlægningen blev iværksat af det danske ministerium for Børn, Ligestilling, Integration og Sociale Forhold for at få viden om, hvordan de offentlige myndigheder i praksis benytter ligestillingsvurderinger i forhold til politikområder og kerneydelser. Kortlægningen er økonomisk støttet af Nordisk Ministerråd. Kortlægningen er gennemført af Oxford Research.

Kortlægningen er baseret på en spørgeskemaundersøgelse blandt 



\section{UDBYTTE AF AT FORETAGE LIGESTILLINGSVURDERINGER}

Kortlægningen viser, at de statslige myndigheder kan opnå resultater i form af øget kvalitet $\mathrm{i}$ kerneydelsen og lige muligheder for borgere, som leder til effekt i form af øget ligestilling, såfremt de foretager ligestillingsvurderinger i forbindelse med deres arbejde.

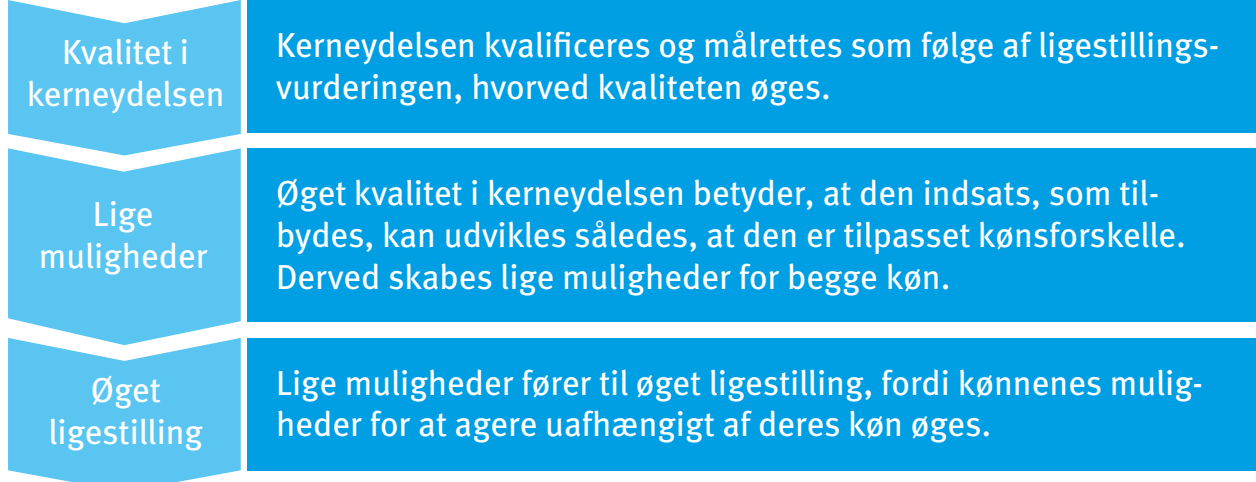

Som ved alle andre indsatser er det nødvendigt at have blik for, hvilke ressourcer og omfanget at disse, som afsættes til arbejdet med ligestillingsvurderinger. Ressourcer fx $\mathrm{i}$ form af afsatte økonomiske midler, medarbejdertimer eller ekstern sparring. Kortlægningen viser, at det er muligt at skabe resultater både ved et begrænset og ved et nævneværdigt brug af ressourcer, hvad end det er økonomiske midler, medarbejdertimer eller ekstern sparring. Det er dog væsentligt at afstemme forventninger til udbyttet med graden af afsatte ressourcer. 



\section{MODEL FOR ARBEJDET MED LIGESTILLINGSVURDERING}

På baggrund af kortlægningen af good practice eksempler er der udviklet en model for arbejdet med ligestillingsvurderinger. Modellen viser, hvordan forskellige led $\mathrm{i}$ arbejdet med ligestillingsvurdering hænger sammen og gensidigt påvirker hinanden.

Model for ligestillingsvurdering

\section{Resultater/ effekter}

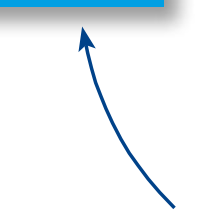

Redskaber

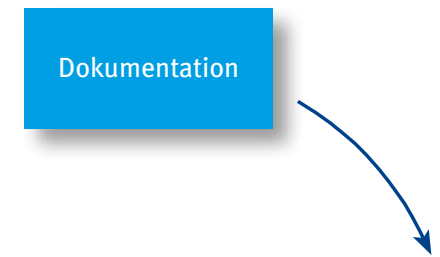

Politik for ligestilling
Første led i arbejdet med ligestillingsvurdering er brugen af dokumentation i form af kønsopdelt data. Data kan enten basere sig på kvantitative eller kvalitative undersøgelser. Disse data bruges til at gennemføre en kønsanalyse. I en kønsanalyse analyseres data i forhold til, om der er forskelle på mænd/drenge og kvinder/pigers adfærd og præferencer, som der skal tages højde for i udviklingen af indsatsen, lovforslaget, kampagnen m.v. Køn kan have betydning i tilfælde, hvor det ikke umiddelbart er synligt eller oplagt, og det er derfor væsentligt at foretage kønsanalyser for at skabe høj kvalitet i indsatsen.

Dokumentation af eventuelle kønsforskelle bør benyttes, når der udvikles politikker, således at politikker på et givent område udvikles på et veldokumenteret grundlag.

Når der er opstillet politikker, formuleres konkrete målsætninger nemmere. Det er væsentligt, for at der kan arbejdes med køn og ligestilling i de forskellige initiativer, at der opsættes konkrete målsætninger og målbare indikato- rer for disse. Målsætninger skaber forudsætninger for, at indsatserne kan målrettes og ramme de relevante personer. Desuden er de også en forudsætning for, at der kan måles og konkluderes på resultater og effekter af indsatser i forhold til ligestilling, og at disse resultater og effekter kan dokumenteres.

Fjerde led i modellen er redskaber. Udvikling og anvendelse af redskaber er essentielt for, at ledere og medarbejdere i offentlige myndigheder har de fornødne kompetencer til at gennemføre ligestillings- 


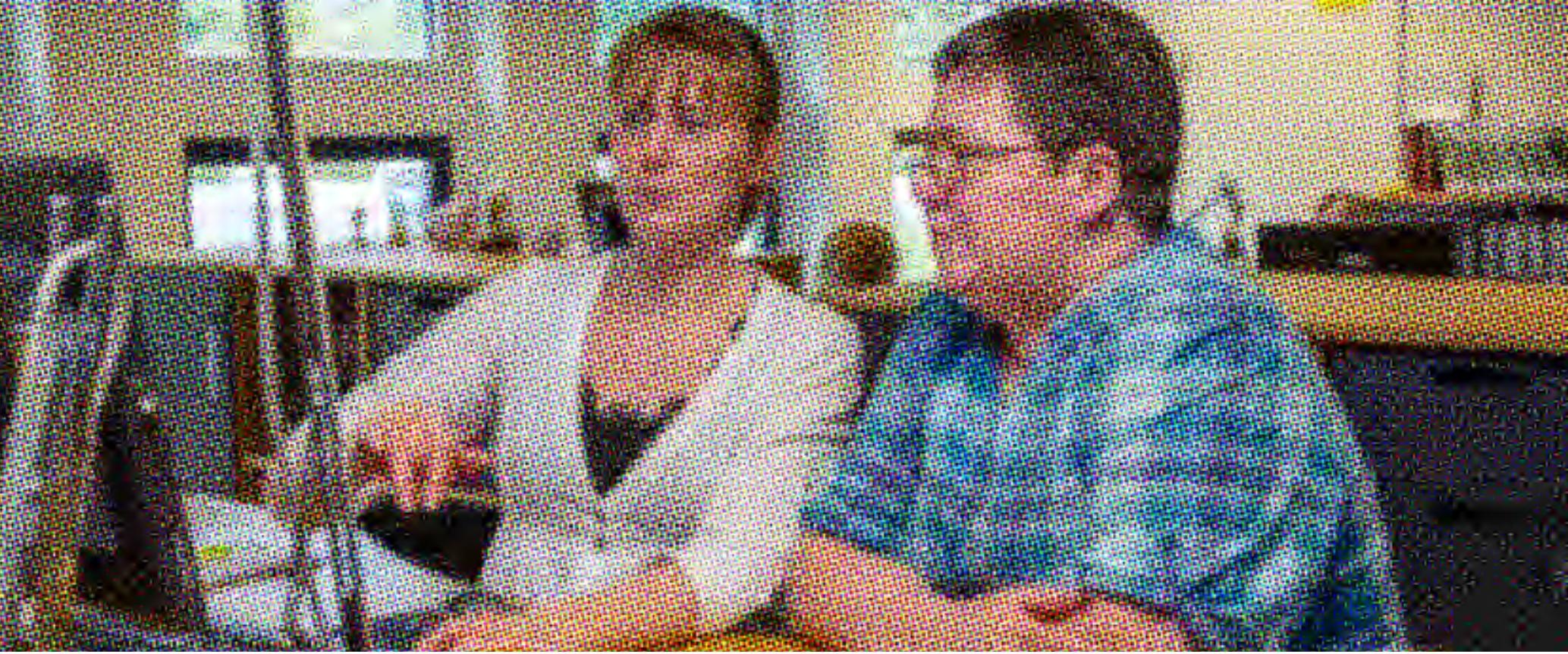

\section{Modellen kan anvendes til at opnå bedst mulige resultater af arbejdet med ligestillingsvurderinger.}

vurderinger. Redskaber dækker over uddannelse i ligestilling og ligestillingsvurdering, procedurer for gennemførelsen af ligestillingsvurderinger samt konkrete værktøjer hertil.

Femte led er resultater og effekter. For at kunne opnå resultater i forhold til kerneydelsen (øget kvalitet) og effekter på ligestilling af en given indsats, er det nødvendigt, at de foregående led i modellen er gennemført.
Det vil sige, at der er udarbejdet politikker for ligestilling, opstillet målsætninger og indikatorer, samt at ledere og medarbejdere i offentlige myndigheder har de fornødne redskaber og kompetencer til at foretage ligestillingsvurderinger. Hvis disse elementer er til stede, og processen følges, vil ministerierne $i$ følge kortlægningen opnå resultater i forhold til kerneydelsen og effekter for ligestilling.

Sidste led i modellen er (igen) dokumentation, idet det er væsentligt, at de opnåede resultater og effekter af en given indsats dokumenteres, således at der bl.a. genereres kønsopdelt data, der aktivt kan anvendes til kønsanalyser i forbindelse med iværksættelsen af nye initiativer. Ved at benytte modellen for ligestillingsvurderinger kan offentlige myndigheder opnå resultater i form af øget kvalitet i kerneydelsen samt øget ligestilling. 


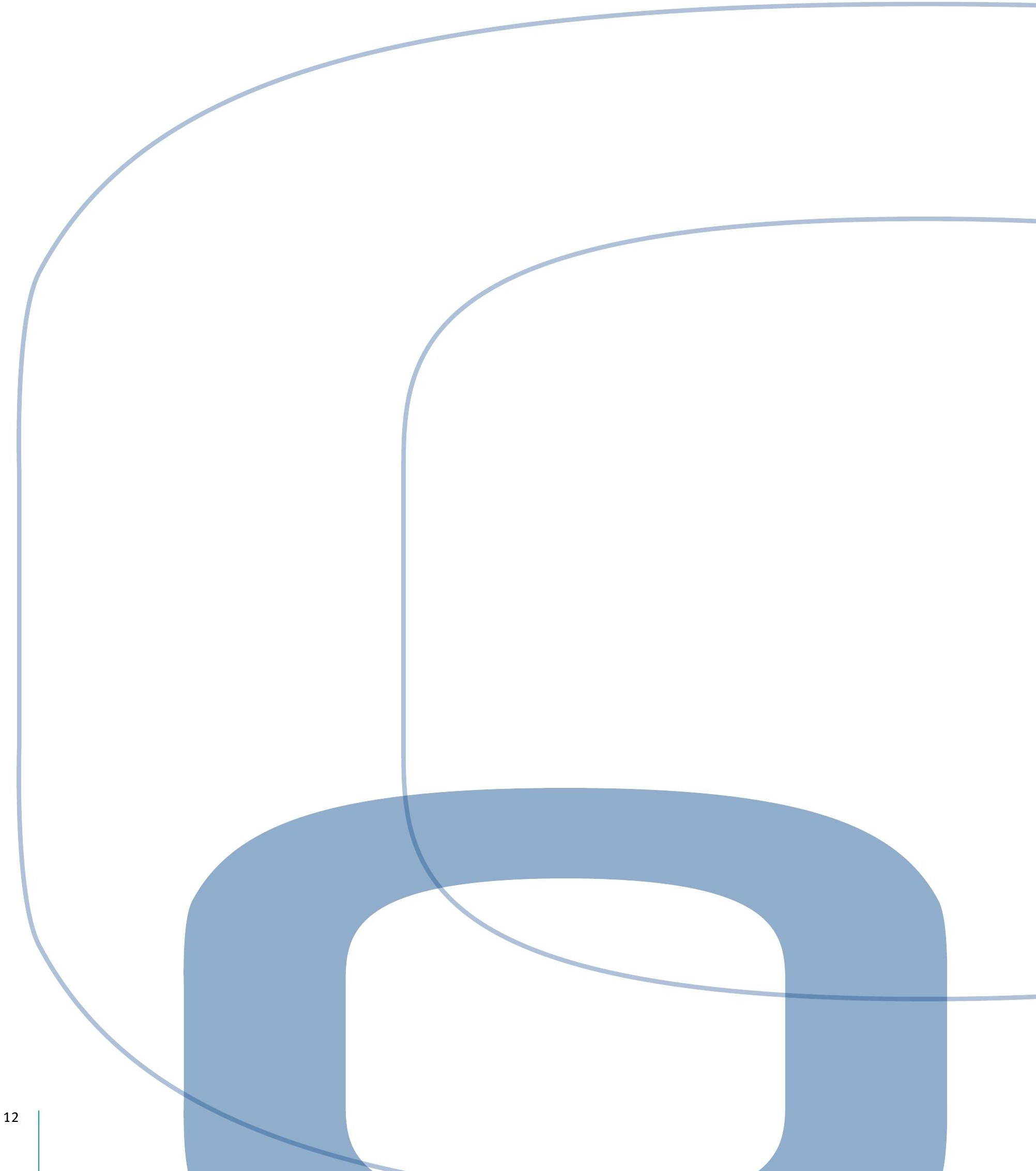




\section{ANBEFALINGER TIL ARBEJDET MED LIGESTILLINGSVURDERING}

I det følgende afsnit præsenteres anbefalinger og konkrete eksempler på arbejdet med ligestillingsvurderinger med udgangspunkt i modellen for arbejdet med ligestillingsvurdering. Anbefalingerne og de konkret eksempler er udledt af kortlægningens analyse. De konkrete eksempler er derfor good practice eksempler på, hvordan forskellige offentlige myndigheder foretager ligestillingsvurderinger. 


\section{1 .1 \\ POLITIK OG MÅLSAETNINGER FOR LIGESTILLINGSVURDERING AF KERNEYDELSER}

At der er opstillet en politik på ressortområdet eller for udvalgte fagområder indikerer, at der er politisk fokus på ligestilling. Ved at have en politik for ligestilling skabes der i højere grad legitimitet omkring ligestilling, da det er prioriteret fra politisk hold. Politikker skaber en overordnet ramme for ministeriernes ligestillingsarbejde, herunder ligestillingsvurderinger af kerneydelser. Det politiske fokus på ligestilling betyder endvidere, at der i højere grad afsættes ressourcer til ligestillingsarbejdet.

Praksiseksemplet illustrerer, hvordan udmøntning af en overordnet politik og en konkret indsats kan gribes an, og hvad det kan bidrage til.
Konkret i forhold til politikker anbefales det:

- at der udarbejdes politikker for ligestilling for de respektive ressortområder, så der skabes en overordnet ramme for arbejdet med ligestilling, således at der opstår øget legitimitet omkring ligestilling. 


\section{1 .2 \\ MÅLSATNINGER FOR LIGESTILLINGSVURDERING AF KERNEYDELSER}

Udover at opstille politikker i forhold til køn og ligestilling, anbefales det, at der opstilles konkrete målsætninger samt målbare indikatorer, således at det er muligt at vurdere og dokumentere resultaterne. Målsætninger kan være meget konkrete, $\mathrm{fx}$ at andelen af mandlige pædagoger skal øges til 20 procent, som tilfældet er i nedenstående praksiseksempel. Mindre konkrete målsætninger kan også udfylde samme rolle, så længe der kan opstilles målbare indikatorer for målsætningen. En målbar indikator for øget ligestilling i børnehaver kan fx være, at flere mænd har søgt ind på pædagogstudiet end året tidligere, eller at flere mænd ansættes som pædagoger i børnehaverne.

Praksiseksemplet viser, hvorfor opstilling af målsætninger er vigtigt for at skabe resultater af ligestillingsarbejdet.
Konkret i forhold til målsætninger anbefales det:

- at der opstilles konkrete målsætninger og operationelle, målbare indikatorer, således at der kan måles og konkluderes på resultater og effekter af indsatser i forhold til ligestilling. 


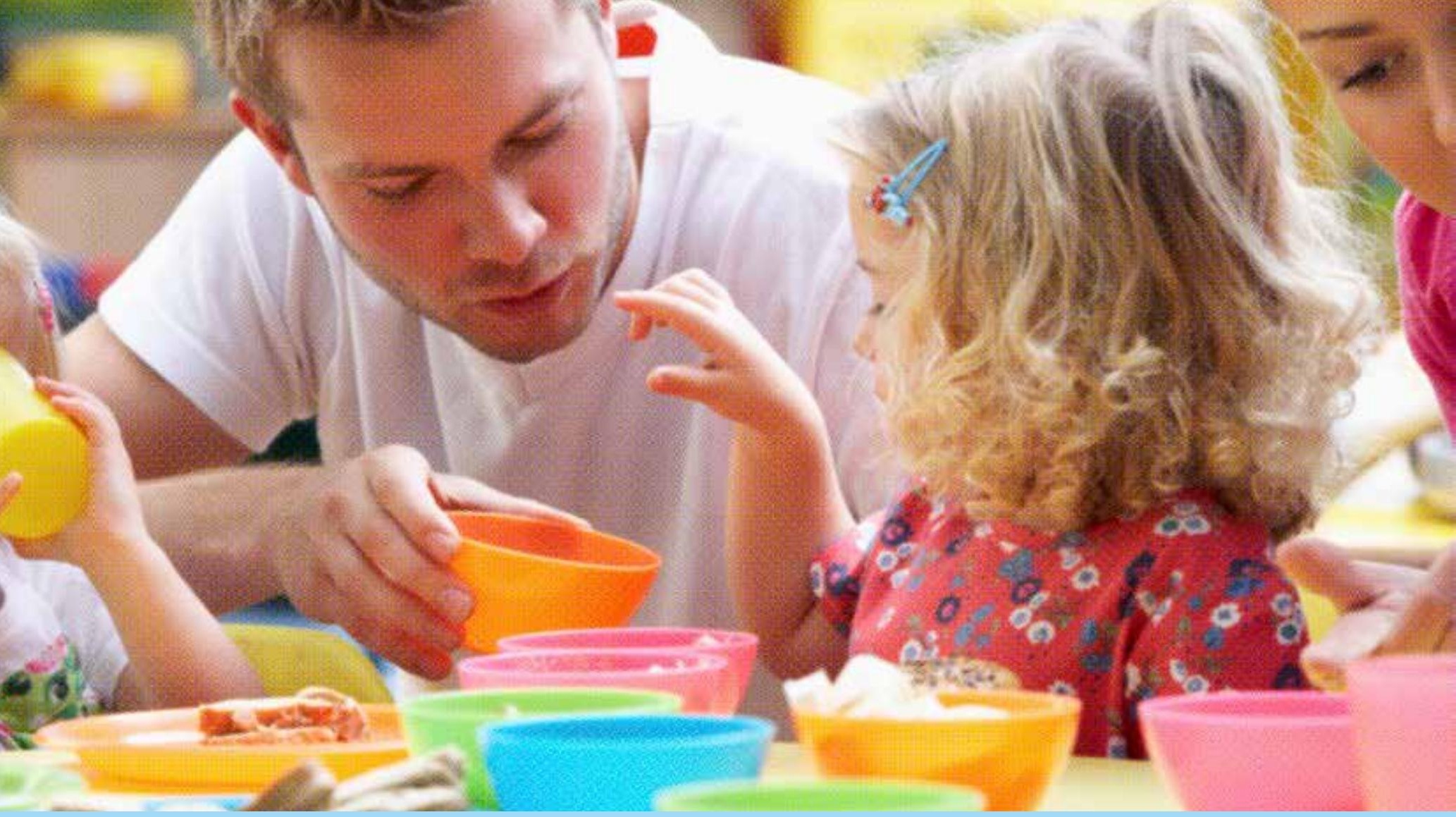

\section{PRAKSISEKSEMPEL}

Eksemplet Kompetanseheving i barnehagene - statlige likestillingstiltak fra Norge viser, at opstilling af målsætninger er vigtigt for at skabe resultater af ligestillingsarbejdet. Der er opstillet en helt konkret målsætning om, at andelen af mandlige pædagoger i børnehaverne skal være 20 pct. Derudover er der en målsætning om, at læringsmiljøet i børnehaverne skal fremme ligestilling. Således er der både opstillet konkrete og direkte målbare målsætninger samt mere overordnede målsætninger.

Den konkrete målsætning om en andel af mandlige pædagoger på 20 pct. bevirker, at projektets resultater hele tiden bliver holdt op imod denne målsætning. Det bliver derfor let at vurdere, om målet er nået. 


\subsection{3 \\ REDSKABER TIL ARBEJDET MED LIGESTILLINGSVURDERINGER}

Faste procedurer og redskaber til brug for ligestillingsarbejdet bidrager til at udvikle og forankre arbejdet med ligestillingsvurdering i ministerierne. Procedurer og redskaber gør det nemmere for medarbejdere og ledelse at arbejde med ligestillingsvurdering, fordi de har konkrete greb at tage fat i, og derved få hjælp til, hvordan de skal gribe arbejdet an. Derudover bidrager faste procedurer til at fastholde fokus på arbejdet med ligestilling i ministerierne.

Men det er ligeledes nødvendigt, at de ledere og medarbejdere, der foretager ligestillingsvurderinger, har de fornødne kompetencer hertil. Derfor er det essentielt, at både ledere og medarbejdere uddannes $\mathrm{i}$ dette arbejde - de skal uddannes/ trænes i dels at foretage kønsanalyser, dels gennemføre ligestillingsvurderinger. Et led heri kan ligeledes være, at ledere og med- arbejdere uddannes i ligestilling, for at der skabes et fælles ståsted og forståelse for vigtigheden af ligestillingsvurderinger.

Tillige kan ligestillingsenheder eller interne ligestillingsrådgivere ( $f x$ i ministerierne) have en fremmende faktor for arbejdet med ligestillingsvurderinger, da de gennem rådgivning bidrager til at give de offentlige myndigheder de fornødne kompetencer til at foretage ligestillingsvurderinger.

Praksiseksemplet viser, hvilke redskaber en offentlige institution har udviklet til arbejdet med ligestillingsvurderinger.

\section{I forhold til redskaber til arbejdet} med ligestillingsvurderinger anbefales det:

- at ledere og medarbejdere, der foretager ligestillingsvurderinger, uddannes i ligestilling og udarbejdelsen af ligestillingsvurderinger af kerneydelser, idet det kræver specifikke kvalifikationer at arbejde med ligestilling og foretage ligestillingsvurderinger.

- at der udarbejdes og benyttes metoder, redskaber og procedurer for arbejdet med ligestillingsvurdering af kerneydelser, idet det sikrer forankring af ligestillingsvurderinger i ministeriet.

- at relevante ligestillingsaktører indgår aktivt som rådgivere i forhold til ministeriernes arbejde med ligestillingsvurderinger. Dette bidrager til at sikre, at ministerierne har de fornødne kompetencer til at foretage ligestillingsvurderinger. 


\subsection{4 \\ RESULTATER OG EFFEKTER \\ - OG DOKUMENTATION HERAF}

Det er væsentligt at dokumentere og dermed synliggøre, at ligestillingsvurderinger påvirker resultater og effekter af en given indsats. I en indsats, hvor ligestillingsvurderingen har vist, at køn er en relevant faktor, er det væsentligt at dokumentere indsatsens resultater og effekter i forhold til ligestilling. På den måde kan resultaterne fremadrettet bruges i udviklingen af politikker, handlingsplaner og konkrete indsatser. Brugen af kønsopdelt data er ligeledes væsentligt $i$ forhold til at målrette initiativer.

Ved at benytte dokumentation som grundlag for et givent initiativ skabes der legitimitet i forhold til initiativet, fordi det baserer sig på et veldokumenteret grundlag. Desuden skabes der legitimitet i forhold til i højere grad at indtænke et ligestillingsperspektiv $\mathbf{i}$ udviklingen af initiativer, politikker, handlingsplaner m.m. Det er derfor essentielt, at der løbende genereres kønsopdelt data i forhold til adfærd, behov og præferencer samt udbytte og effekt af konkrete indsatser, som kan danne udgangspunkt for fremtidige indsatser.

Praksiseksemplet illustrerer, hvordan kønsopdelt data er brugt til udvælgelse af målgruppe til en kampagne.

\section{I forhold til resultater og effekter anbefales det:}

- at der indsamles kønsopdelt data. Der kan eksempelvis stilles krav om kønsopdelt data ved afrapportering af resultater og effekter af de statslige myndigheders arbejde.

- at kønsopdelt data benyttes til foranalyser, inden indsatser iværksættes, således at det sikres, at kønsaspektet er indtænkt $\mathrm{i}$ indsatsen, da det skaber øget kvalitet i kerneydelsen.

- at resultater og effekter i forhold til øget bevidsthed om ligestilling dokumenteres. Dette kan synliggøre, at indsatser iværksat af ministerierne skaber øget ligestilling og lige muligheder for kønnene.

- at resultater og effekter af arbejdet med ligestillingsvurdering $i$ højere grad synliggøres og udbredes til relevante aktører. Dette gælder på flere niveauer, på politisk, ledelses- og medarbejderniveau samt i forhold til borgere og interessenter. En synliggørelse heraf vil bidrage til, at der skabes opbakning til ligestillingsarbejdet. 


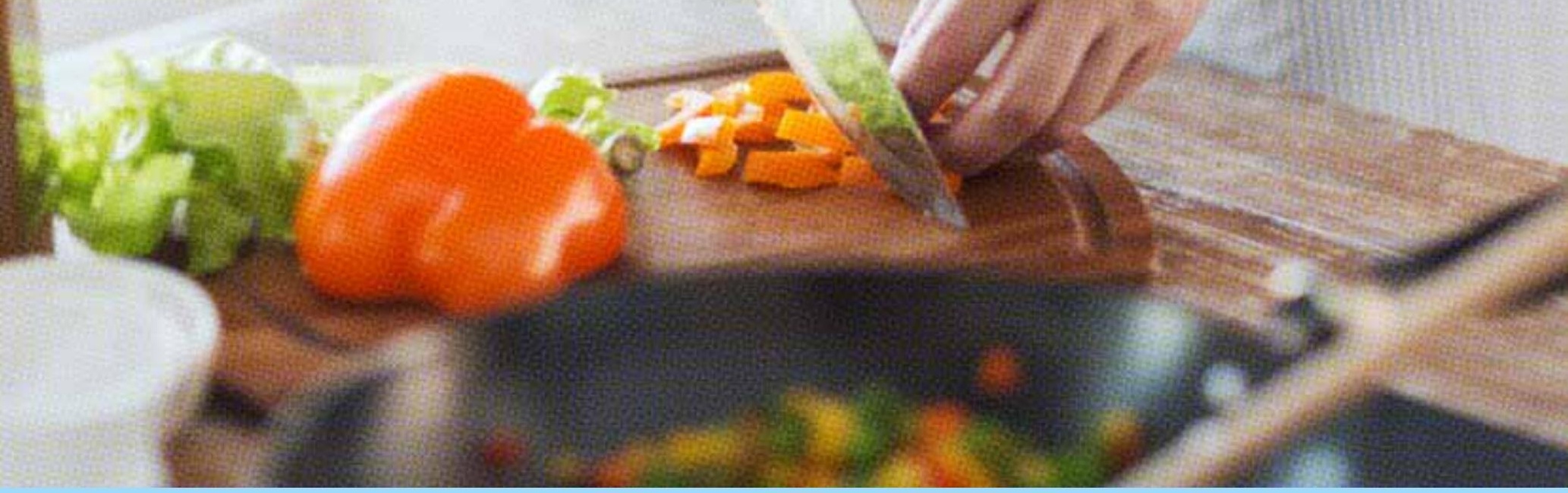

\section{PRAKSISEKSEMPEL}

I nøglehulsmærkets kampagne Herrefedt! fra Danmark er der gennemført en kønsanalyse på baggrund af kønsopdelt statistik om mænd og kvinders sundhed og spisevaner til at udvælge målgruppen for kampagnen. Kampagnen er målrettet ufaglærte og kortuddannede mænd +35 år, idet dokumentation (kvalitativt og kvantitativt) viser, at denne gruppe har et dårligere helbred end andre grupper i samfundet, samt at målgruppen i mindre grad har kendskab til nøglehulsmærket.

Kampagnen havde til formål at få særligt denne målgruppe til at handle sundere og træffe sundere fødevarevalg. Kampagnen hedder 'Herrefedt' for at fange mændenes opmærksomhed blandt andet via en brochure med forsidebillede af en mandearm med en stor kødkniv $i$ hånden, og der er benyttet mørke farver, som via anden dokumentation er bevist tiltaler mænd. Desuden er der afholdt en række events rundt omkring $i$ landet med blandt andet en mandlig kok, der laver mad med Nøglehulsprodukter. Dette er begrundet i, at kampagneteamet har været bevidste om, at det var vigtigt at opsøge mændene, idet det er en svær målgruppe at nå.

Kampagnen er et godt eksempel på, hvilke overvejelser der ligger bag en kampagne, der primært er målrettet mænd, og dermed hvordan kønsaspektet er tænkt ind i udviklingen af kampagnemateriale og events. Desuden er kampagnen et godt eksempel på et initiativ, der er målrettet det ene køn, men hvor det sikres, at det andet køn (i dette tilfælde kvinder) ikke ekskluderes ved også at tænke dette køn ind ved udvikling af kampagnematerialet.

Inddragelse af målgruppens køn i udarbejdelsen af kommunikationsmateriale kan bidrage til i højere grad at målrette et givent materiale og dermed i højere grad ramme den specifikke målgruppe af borgere. Ressourcerne anvendes derfor optimalt. Et eksplicit fokus på ligestilling $i$ kommunikationsmateriale kan ligeledes bidrage til at synliggøre, at der er et ønske fra myndigheden i forhold til at skabe ligestilling. 


\section{YDERLIGERE VIDEN}

For mere viden om kortlægningen og resultaterne heraf henvises til rapporten Kortlægning af good practice og effekter i de offentlige myndigheders arbejde med ligestillingsvurdering på udvalgte serviceområder - statsligt niveau. Rapporten er udarbejdet af Oxford Research A/S, september 2014.
Kortlægningen indeholder en analyse af de statslige myndigheder arbejde med ligestillingsvurdering $i$ Norden på baggrund af dels en spørgeskemaundersøgelse blandt samtlige ministerier i Norden, dels 11 good practice eksempler på nordiske myndigheders arbejde med ligestillingsvurderinger. Derudover bygger analysen på en gennemgang af de politiske, juridiske, økonomiske og kulturelle hovedtræk i de nordiske lande (nationale kontekster) for arbejdet med ligestillingsvurdering.

\section{DANMARK}

Oxford Research A/S

Falkoner Allé 20

2000 Frederiksberg

Danmark

Tel: (+45) 33691369

office@oxfordresearch.dk
NORGE

Oxford Research AS

Østre Strandgate 1

4610 Kristiansand

Norge

Tel: (+47) 40005793

post@oxford.no
SVERIGE

Oxford Research AB

Norrlandsgatan 11

10393 Stockholm

Sverige

Tel: (+46) 08240700

office@oxfordresearch.se
FINLAND

Oxford Research Oy

Helsinki:

Fredrikinkatu 61a, 6krs

00100 Helsinki, Suomi

www.oxfordresearch.fi

office@oxfordresearch.fi
BRUXELLES

Oxford Research

C/o ENSR

5. Rue Archiméde

Box 4, 1000 Brussels www.oxfordresearch.eu office@oxfordresearch.eu 
14. A4 ${ }^{2}$ H r 4.

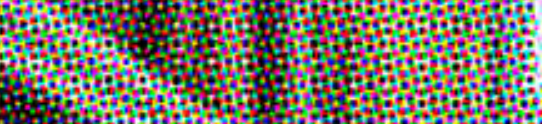
(4) 20.7.
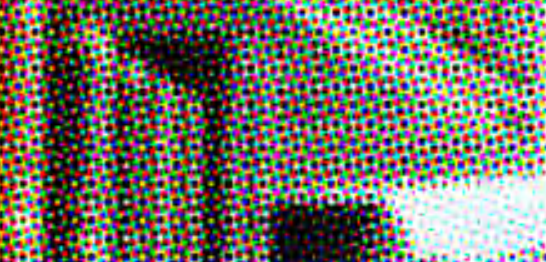

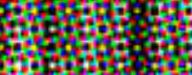
57 ing.

ting

H.

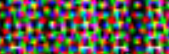

(f)

Heq

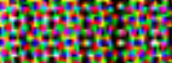

12017

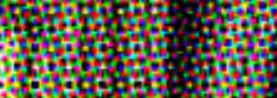

ingeng ing
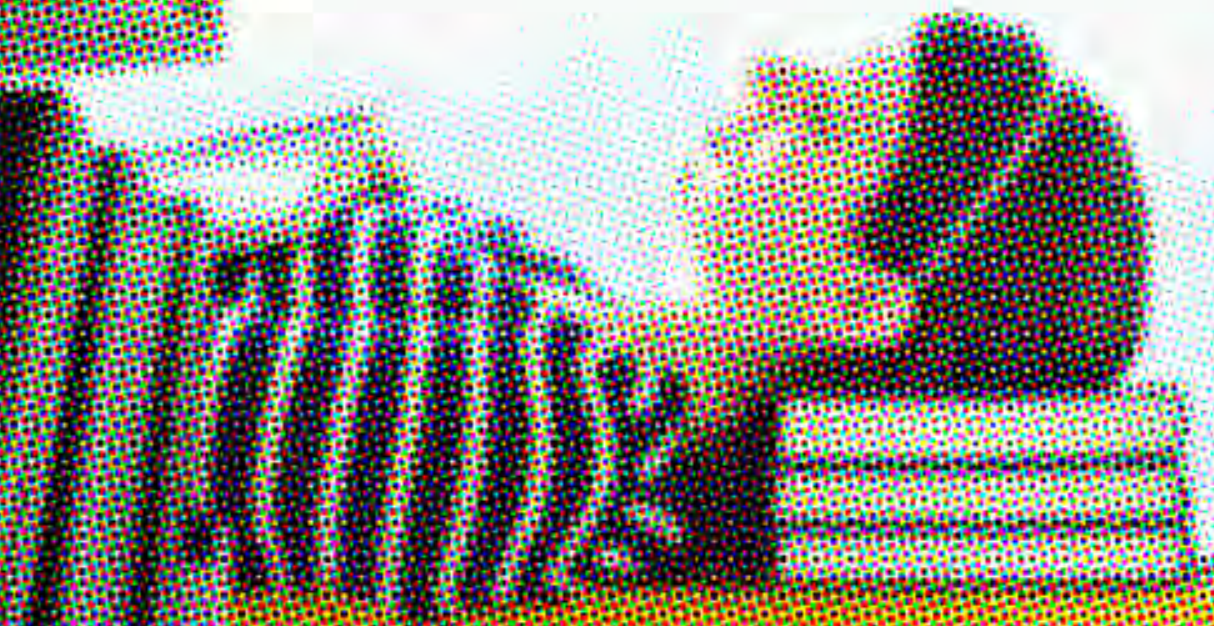

owntherat

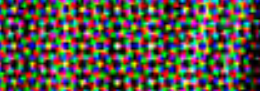

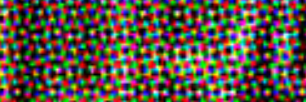

and

Mas.

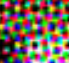

P.:

4

207 ing

4 and 0 (x) 48

17.

ragate

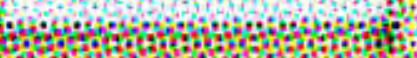

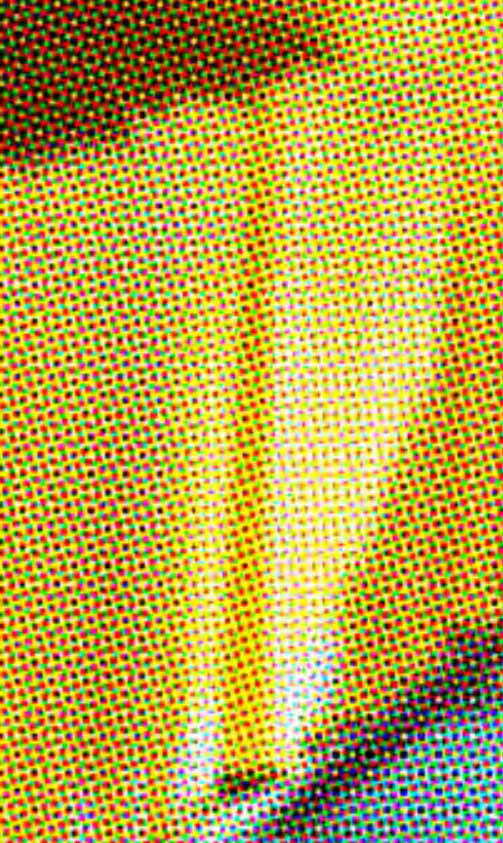

0.0.9.

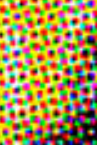
7 ingang 


\section{norden}

Nordic Council of Ministers

Ved Stranden 18

DK-1061 København K

www.norden.org

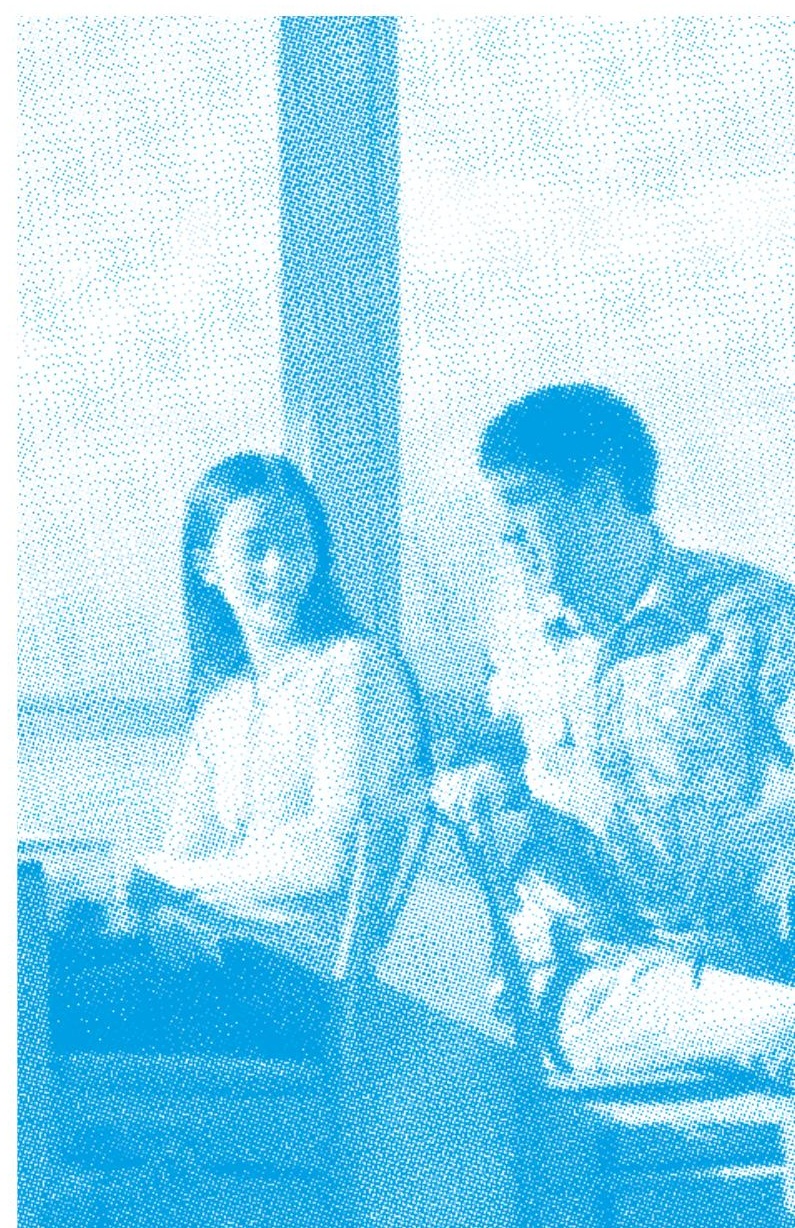

